\title{
Tourism Education at the Tertiary Level and Competitive Advantage: A Comparison between Thailand and Malaysia
}

\author{
Thavorn Thitthongkam, John Walsh* \\ School of Management, Shinawatra University, Thailand \\ *jcwalsh@siu.ac.th
}

\begin{abstract}
Language plays an imperative role in business as a means and a source of power. It is particularly important in the tourism industry when international customers may be unable to communicate directly with service providers in the receiving country, and this has a direct effect on the level of satisfaction that they enjoy during their experience. To address this issue, countries attempt to various degrees to manage their labour markets so as to produce a number of graduates from secondary and tertiary level educational institutions commensurate with the demand from the sector. However, this is quite a young industry at the global level, and it is not clear to what extent the number and quality of such graduates with international language ability will be required. This paper studies the comparative extent of such education at the tertiary level of individuals in both Thailand and Malaysia. It aims to compare the number and variety of people being trained in the tourism and hospitality industry and the extent to which languages are being taught. Results show that there is something of a disconnection between the languages provided and the languages that tourists desire in terms of their mother tongue. Those tourists who can speak English or Chinese may receive service support in those languages, while those who cannot may be disappointed.
\end{abstract}

\section{Keywords: Tourism education, competitiveness, Language, Tourism in Thailand, Tourism in Malaysia}

\section{Introduction and Literature Review}

Tourism is one of the world's most important and most rapidly expanding industries and statistics suggest that the economic consequences of tourism will also continue to grow. According to the Tourism Authority of Thailand (TAT), Thailand welcomed 14.46 million international tourists in 2008 (Thitthongkam \& Walsh, 2009). The target for 2010 is 17 million international tourists. Malaysia reached 23.65 million international tourists in 2009. By 2010, the Thai tourism industry and the Malaysia tourism industry expect to reach higher records in terms of international tourists and revenues. As a result, the demand for tourism industry employment will also increase. The figures show that tourism education at the tertiary level of both countries has to work hard to produce graduates for this industry. Current and future employees should be provided with opportunities to increase the levels of satisfaction of international tourists. Accordingly, the tourism industry leaders and educators have to be concerned with the quality and development of the workforce. Noticeably, tourism education is more often an issue for discussion, particularly in institutions at the tertiary level.

Language plays a vital role in business as a means and a source of power. It is particularly important in the tourism industry when international customers may be unable to communicate directly with service providers in the receiving country, and this has a direct effect on the level of satisfaction that they enjoy during their experience. Both Thailand and Malaysia have attempted to various degrees to manage their labour markets so as to produce a number of graduates sufficient for the demand from the industry. However, this is rather a young industry at the global level, and it is not clear to what extent the number and quality of such graduates with international language ability will be required. This paper aims to study the comparative extent of such education at the tertiary level of individuals in both Thailand and Malaysia. It also aims to compare the number and variety of people being trained in the tourism and hospitality industry and the extent to which languages are being taught.

\section{Definition of Tertiary Level}

The word "tertiary level" refers to official postsecondary education institutions that educate professional personnel at the degree level (Lee, 2004) or higher education. It includes diploma and vocational certificate in specific area. 


\section{Tourism in Thailand}

Tourism has been one of the largest industries in Thailand since the late 1950s (Cohen, 1996:2). This means that tourism started in earnest in the period of King Rama IX. However, tourism truly took off when US soldiers started to arrive in the 1960s for Rest and Recreation (R\&R) during the Vietnam War period (Ouyyanont, 2001; Da Silva, 2002). Correspondingly, international mass tourism sharply increased during the same period due to the rising standard of living, more people acquiring free time and due to improvements in technology making it possible to travel further, faster, cheaper and in greater numbers, as symbolized by the Boeing 747 which first flew commercially in 1970. Thailand was one of the major players in Asia in capitalizing on this. The tourism industry has played an important role in Thailand in increasing revenues for the country. According to the TAT (TAT, 2007), the revenue generated from international tourists that Thailand earned was TH\$547,782 million or around US\$15,877 million (Thitthongkam \& Walsh, 2009).

\section{Tourism Education at Tertiary Level in Thailand}

Tourism education has been a part of Thai education at the tertiary level for more than 30 years. The travel and tourism education in Thailand at an undergraduate level was first offered in the Faculty of Commerce and Accountancy, Chulalongkorn University in 1955 under the Bachelor of Commerce Degree with a major field of study in "Travel Management. Later, Prince of Songkla University (PSU) brought the concept of community college from the U.S.A. to put into action by setting up Phuket Community College by offering 2-year diploma program in Hotel and Tourism Management to meet the staff requirement of tourism industry in Phuket in 1977. This indicates that tourism education expanded in the late 1970s, and expanded quickly in the early 1990s (McKercher, 2002), and during 2001-2006 showed some of the greatest improvements in tourism education. Yet, it is not clear to what extent the number and quality of such graduates with international language ability will be required for quite a young industry at the global level. The quick changes in tourism education at the tertiary level in Thailand occur (Sangpikul, 2009) because of globalization, the rapid expansion of tourism education in the early 1990s (McKercher, 2002), and the rapid expansion of the tourism business (Saibang and Schwindt, 1998). The primary contribution of tourism education at the tertiary level in Thailand is its capacity to generate employment, and it can be a key means to support Southeast Asia cooperation by emphasizing the similarities of cultures, ethnic groups, history and ways of life (Toatong, 2008). This includes creating common supportive functions leading to better harmony in the entire region. Tourism has indeed played a crucial role in the growth of Thai economy (Chon, et al., 1993).

Tourism education at the tertiary level in Thailand compared to Malaysia is better developed. More Thai universities with good quality offer tourism education. This paper disagrees with the study done by Toatong (2008), which claimed that tourism education in Malaysia is more developed and observes that many universities are providing tourism education. However, the Tourist Development Corporation (TDC) has played an important role in promotion campaigns both locally and overseas to improve the success of the tourism industry in Malaysia by attracting large numbers of international tourists and, thereby, earning considerable revenue (Poon \& Low, 2005). Universities as tourism education providers in Thailand are now faced with a progressively more competitive situation as the tourism market in Thailand faces a slowdown caused by political disturbance, economic recession and global pandemic outbreaks. Nevertheless, new tourism education providers are still entering the market because of medium- and long-term prospects.

\section{Tourism in Malaysia}

According to Khairudin (2009), tourism in Malaysia was not achieved before the 1970s when agriculture was the primary segment in the market (Baum, 2006). Only in 1972, was thoughtful concentration given to developing tourism as a segment of the market, through the plan of the TDC under the Ministry of Trade and Industry. The flourishing notability of tourism in the country led to the establishment of the Ministry of Tourism in 2004 to focus on tourism development as a source of growth (Ministry of Tourism, 2008). The Ministry of Tourism is also sustained by Tourism Malaysia, the organization principally responsible for the creation and enactment of marketing strategies in Malaysia (Tourism Malaysia, 2008b). The geographical characteristics of Malaysia have set apart its tourism industry with a wide range of natural attractions which include beaches and islands, mountains and hill resorts, caves, forests and nature parks (Wells, 1982). Moreover, the multiplicity of the racial groups in Malaysia also 
contributes to the combination of individual cultures, traditions, and festivals which are often promoted as highlights for tourists visiting the country (Tourism Malaysia, 2008a).

In terms of its tourism marketing strategy, Malaysia focuses on Japan, China, Australia, the Middle East and Southeast Asia for high volumes of inbound tourists. Tourism is the second highest foreign exchange earner for the Malaysian economy, after manufacturing, with a total of US\$1.35 billion in 2008 (Tourism Malaysia, 2008c). Subsequently, the demand for people who are knowledgeable in foreign languages and skill in tourism and related fields remains enormous and provides many career chances. This results in rapid development to try to meet needs. Development can be seen clearly from the increase of both the numbers of educational institutions at the tertiary level and the available programs in tourism education and related fields to develop tourism human resources. Conversely, Chaisawat (2005) commented that there were problems in terms of excellence of graduates because their qualifications were not up to the standards required by the employers. Questions are being asked about the sustainability of the growth and it is predicted that the tourism education program is not unstoppable.

\section{Tourism Education Institutions at Tertiary Level in Thailand}

In previous years, there were few institutions that provided the programs in tourism and related fields at the tertiary level. Presently, 15 public universities, 32 private institutions, 34 Rajabhat universities, and 8 Rajamangala Universities of Technology offer tourism education (Office of the Higher Education Commission, 2009). The public universities where tourism education is offered include Burapha University, Chiang Mai University, Kasetsart University, Khon Kaen University, Maejo University, Phrae Campus, Mahasarakham University, Mahidol University, Naresuan University, Prince of Songkhla University, Phuket Campus, Ramkhamhaeng University, Silpakorn University, Srinakharinwirot University, Sukhothai Thammathirat Open University, Ubon Rajathanee University, and Walailak University. The private universities where tourism education is offered consist of Sripatum University, Assumption University, Bangkok University, Bangkok Thonburi University, Bangkoksuvanabhumi College, Christian University of Thailand, Dhurakij Pundit University, Dusit Thani College, Eastern Asia University, The Far Eastern University, Huachiew Chalermprakiet University, Kasem Bundit University, Krirk University, Lampang-Inter-Tech College, Nakhon Ratchasima College, North Bangkok College, North-Chiang Mai University, Pathumthani University, Payap University, Pitsanulok College, Rajapark College, Rangsit University, Ratchapruek College, Ratchathani University, Rattana Pundit University, Saint John's University, Siam University, Sripatum University, Schiller-Stamford, University of the Thai Chamber of Commerce, Tapee College, Vongchavalitkul University, and Yonok University.

The Rajabhat Universities where tourism education is offered include Chiang Rai Rajabhat University, Chiang Mai Rajabhat University, Kamphaeng Phet Rajabhat University, Udon Thani Rajabhat University, Ubon Ratchathani Rajabhat University, Lampang Rajabhat University, Nakhon Sawan Rajabhat University, Pibulsongkram Rajabhat University (Pitsanulok), Maha Sarakham Rajabhat University, Nakhon Ratchasima Rajabhat University, Nakhon Si Thammarat Rajabhat University, Buri Ram Rajabhat University, Rajanagarindra Rajabhat University, Thepsatri Rajabhat University, Phranakhon Si Ayutthaya Rajabhat University, Rambhibarni Rajabhat University (Chantaburi), Kanchanaburi Rajabhat University, Nakhon Pathom Rajabhat University, Phuket Rajabhat University, Suratthani Rajabhat University, Chandrakasem Rajabhat University, Thonburi Rajabhat University, Suan Dusit Rajabhat University, Suan Sunandha Rajabhat University, Phetchaburi Rajabhat University, Phetchabun Rajabhat University, Loei Rajabhat University, Rajabhat University, Sakon Nakhon Rajabhat University, Petchburiwittayalongkorn Rajabhat University, Uttaradit Rajabhat University, Phra Nakhon Rajabhat University, Bansomdejchaopraya Rajabhat University, and Surin Rajabhat University. The Rajamangala Universities of Technology where offer tourism education include Rajamangala University of Technology Rattanakosin Wang Klai Kangwon Campus, Rajamangala University of Technology Suvarnabhumi Wasukri Campus, Rajamangala University of Technology Krungthep, Rajamangala University of Technology Rattanakosin Bophit Phimuk Chakkrawat, Rajamangala University of Technology Bangkok Commerce Campus, Rajamangala University of Technology Borpitpimuk Mahamek, Rajamangala University of Technology Lanna Chiang Mai, and Rajamangala University of Technology Srivijaya Songkhla Campus. 


\section{Results and Discussion}

The information indicates that the tourism education and related fields in Thailand at the tertiary level were offered in various departments, schools and faculties as shown in Table 1.

Table 1: Distribution of Departments/ Schools/ Faculties where Tourism Education Courses and Related Fields are being offered at the Tertiary Level in Thailand

\begin{tabular}{lrl}
\hline Department/ School/ Faculty & Absolute Frequency \# & Relative Frequency (\%) \\
\hline Management Sciences & 25 & 28.09 \\
Humanities and Social Sciences & 21 & 23.59 \\
Liberal Arts & 20 & 22.47 \\
Business Administration & 13 & 14.61 \\
Tourism and Hotel Management & 6 & 6.74 \\
Applied Liberal Arts & 2 & 2.24 \\
Archaeology & 1 & 1.13 \\
Communication Arts & 1 & 1.13 \\
Total & $\mathbf{8 9}$ & $\mathbf{1 0 0}$ \\
\hline
\end{tabular}

Tourism education at the tertiary level in Thailand is being offered in various faculties. Usually, it is located in Management Sciences, Humanities and Social Sciences, Liberal Arts and Business Administration. This confirmed the study by Toatong (2008) which indicated that educational institutions in Thailand offered a wide range of programs in tourism such as tourism industry, Hotel and Tourism, Hospitality Service, Tourism Management and most of these engage students in different areas of tourism education. To complete the tourism education program, students are required to take courses adding up to 126 credit-hours or over. It was also observed that some universities participated in contributing graduate courses. Still, information about tourism education serves the core philosophy of the tourism plan created by the Ministry of Tourism and Sport which aims to build up Thailand to become the tourism capital of Asia (Chon et al., 1993; Chaisawat, 2005). Even though there is an increase in the number of universities and students, it is too early to say that it has had a positive or negative impact on Thai tourism competitiveness. One of the reasons is that the number of graduates who will get into the tourism labour market will also increase. This is not an issue if unemployment rate in Thailand improves in a positive direction.

Undeniably, it is the right path that the source of tourism development is considered to a main area by human resources, which will lead to resourceful, high quality services and maintain tourism competitiveness. Tourism education helps provide high quality broad-based studies that help to develop students' perspectives to the fullest and enables them to develop into professionals. Most institutions at the tertiary level in Thailand, where tourism education and associated fields are available, provide internship projects. Some of them make plans for opportunities in support of students to obtain experience abroad and create a close set of connections (Toatong, 2008) with hotels, airlines, travel agencies and overseas educational institutions. This means that tourism education considers the issue of work experience, which is also observed by Busby (2001). No matter what, graduates, principally, in the first level managerial positions, must be able to deal with the complex technical operations of tourism operations (Knowles et al, 2003). The programs are designed to assemble tourism industry requirements, to open up career paths and to manage tourism and related businesses. The degree will direct students to specialize as tour entrepreneurs, tour operators, travel consultants, hotel managers and so forth. This supports the idea that education is the mean of fostering individuals and their development. Focusing on foreign languages, a range of languages is offered within programs in Thai tourism education at the tertiary level. They are English, Chinese, Japanese, French, German, Spanish, Arabic, Bahasa Malay, Khmer, Vietnamese, Korean and Russian.

The study by Punmunin (1993) revealed that about 22 percent of tourism industry employees graduated from tertiary level. They were proud as employees because they got more opportunities to advance their foreign language skills, especially English. This is suggested that tourism staff should have the opportunities to obtain tourism education and foreign language at the tertiary level. Ideally, they can increase the quality of service. Another suggestion is that skilled people in the subject and the curriculum should be brought into the workplace. Not surprisingly, improving and maintaining competitiveness by providing education in tourism and foreign languages helps to generate a good environment. As Gossling (2003) pointed out, the provision of tourism education at the tertiary level has been positive in: 
- $\quad$ Raising administration and the industry's willingness to devote itself to tourism education;

- $\quad$ Providing prospective participants and existing tourism employees with the mean to further their tourism education;

- Increasing the number of employees with tourism knowledge and foreign language skills; and

- $\quad$ Contributing to sustainable tourism development through academia's involvement in tourism planning projects.

Interestingly, there are still numerous miscellaneous problems about tourism education at the tertiary level in Thailand. These include dilemma about programs, tourism courses, the employment of graduates and communication (Churchward and Riley, 2002) and particularly foreign languages. In this respect, investigation into the matters helps provide a clearer picture of tourism education at the tertiary level in Thailand as it may be in the future. It is significant that attempts are required to persist since it provides insights into the current and future practices of tourism education (Ernawati, 2002) at the tertiary level in Thailand. To summarize, tourism education at the tertiary level in Thailand is a part of the Thai tourism industry competitiveness. Language plays an important role as a means and a source of power (Lauring, 2007). With respect to the role of language, it is emphasized that some points concerning tourism education at the tertiary level in Thailand will lead to competitiveness in the Thai tourism industry.

\section{Tourism Education Institutions at the Tertiary Level in Malaysia}

The fast growth of the tourism market in Malaysia has brought to light the urgent need to expand the supply of skilled staff in the industry (Goldsmith \& Zahari, 1994). The development resulted from the accomplishment of the Visit Malaysia Year. This led to the lack of skilled labour; in spite of this, the solution was recruiting skilled personnel at the managerial level from overseas because tourism education institutions in Malaysia were not sufficiently expert to address the need. To strengthen the economy in Malaysia, the Government recognized the significance of tourism education at the tertiary level. Tourism education at the tertiary level in Malaysia is supported by the Ministry of Education and Higher Education, Malaysia. Only a few government universities provide tourism education at the tertiary level. Community colleges, private universities and a foreign branch campus university also offer tourism education to meet the need of skilled labour for tourism and related industries.

The MARA Institution of Technology or ITM (School of Hotel and Tourism Management) was first set up in 1967 as a tourism educational institution in Malaysia. It offered diploma and vocational certificate courses at the beginning. Later, at the end of 1993, undergraduate programs in Tourism Education started (Goldsmith \& Zahari, 1994). This indicates that tourism education in Malaysia is a key in Malaysian education at the tertiary level. It appears that tourism education is not a new matter in Malaysia. Presently, the School of Hotel and Tourism, University of Technology MARA (UiTM) offers a degree in Tourism Management. Soon after, University of Malaysia Sabah (UMS) provided a degree in Hotel Management in the Faculty of Business and Economics. Up till now, there are at least 50 institutions providing tourism and related programs. The clear expansion in the tourism education in Malaysia has taken place since 1970. In 1972, when the Government established the TDC with the aim of increasing foreign issues; providing flourishing employment opportunities; developing potential tourism attractions, particularly in specific localities; and the motivation of individuals. In 1986, there was a Promotion of Investment Act that granted inspiration. In 2009, the tourism industry in Malaysia began to really boom for the first time since the marked drop between 1990 and 1992 because of the $1^{\text {st }}$ Gulf War.

Tourism education at the tertiary level in Malaysia is beneficial to both public and private tertiary institutions. Previously, the Government played a more dynamic role in tourism education at the tertiary level. Educational institutions at the tertiary level in Malaysia now, both Government and private universities, offer courses because the Malaysia Government has invested heavily in tourism as a response to both social and economic demands (Lee, 2004). A real and enormous change in tourism education in Malaysia was made when the duration of degree courses was shortened from four to three years so that the shortage of skilled manpower in tourism industry could be overcome. Another significant development was the emphasis on English, which is used as a medium of instruction at the tertiary level. There is a foreign university branch campus in Malaysia, namely Curtin University of Technology, Sarawak Campus. It was founded in 1999. The original university country is Australia. It offers Tourism Management Marketing at the Bachelor of Commerce level. This reflects the improvement of confidence in Malaysia as a provider of quality education. 
Success in tourism education in Malaysia depends on encouraging and taking care of government universities, private universities, community colleges and foreign branch campus universities. However, to win and be able to maintain competitiveness, tourism organizations related also the need to play active roles can be seen in the case of the TDC in providing tourism education to people to generate enough numbers of skilled staff to meet the need for new employees. As the major earner of foreign exchange, tourism has the capability to generate employment (Ernawati, 2002). Tourism education fulfills the needs. Evidently, the main causes for the change of tourism education at the tertiary level in Malaysia are the growth of international arrivals, the demand for skilled employees and the lack of tourism industry experience.

Table 2: Tourist Arrivals in Malaysia by Country, 2008/2009

\begin{tabular}{lccc}
\multicolumn{1}{c}{ Country of Residence } & $\mathbf{2 0 0 8}$ & $\mathbf{2 0 0 9}$ & \% Change \\
\hline Singapore & $11,003,492$ & $8,261,037$ & -24.9 \\
Thailand & $1,493,789$ & 969,610 & -35.1 \\
Indonesia & $2,428,605$ & $1,522,388$ & -37.3 \\
Brunei Darussalam & $1,085,115$ & 687,065 & -36.7 \\
Philippines & 397,884 & 295,896 & -25.6 \\
Vietnam & 122,933 & 104,565 & -14.9 \\
Cambodia & 35,464 & 27,519 & -22.4 \\
China (Include Hong Kong, Macao) & 949,864 & 660,940 & -30.4 \\
Japan & 433,462 & 258,387 & -40.4 \\
Taiwan & 190,979 & 139,359 & -27.0 \\
Rep. of Korea (South Korea) & 267,461 & 158,032 & -40.9 \\
India & 550,738 & 376,313 & -31.7 \\
West Asia & 264,338 & 203,576 & -23.0 \\
Saudi Arabia & 74,632 & 54,098 & -27.5 \\
United Arab Emirates & 34,994 & 17,365 & -50.4 \\
Iran & 63,165 & 65,471 & 3.7 \\
Canada & 77,664 & 59,865 & -22.9 \\
United States of America & 223,249 & 153,624 & -31.2 \\
Australia & 427,076 & 323,218 & -24.3 \\
New Zealand & 56,117 & 40,033 & -28.7 \\
United Kingdom & 370,591 & 290,060 & -21.7 \\
Scandinavian & 117,094 & 80,307 & -31.4 \\
Denmark & 23,817 & 18,507 & -22.3 \\
Finland & 23,112 & 13,424 & -41.9 \\
Norway & 21,516 & 15,276 & -29.0 \\
Sweden & 48,649 & 33,100 & -32.0 \\
The Netherlands & 90,802 & 76,104 & -16.2 \\
France & 86,030 & 76,834 & -10.7 \\
Germany & 111,525 & 85,838 & -23.0 \\
Switzerland & 26,489 & 19,578 & -26.1 \\
Russia Republic & 26,308 & 19,003 & -27.8 \\
Poland & 11,745 & 7,614 & -35.2 \\
Italy & 38,945 & 33,688 & -13.5 \\
Turkey South Africa & 8,152 & 5,694 & -30.2 \\
Others & 25,437 & 14,334 & -43.6 \\
& $1,131,140$ & 430,024 & -62.0 \\
Sources & $\mathbf{2 2 , 0 5 2 , 4 8 8}$ & $\mathbf{1 5 , 3 8 0 , 5 0 5}$ & -30.3 \\
\hline
\end{tabular}

Source: http://www.tourism.gov.my/.

The number of international tourist arrivals to Malaysia has increased from 1.1 million tourists in 1974 to 17.5 million tourists in 2006. A special tourism campaign, 'Visit Malaysia Year', resulted in a total of 20.97 million international visitors in 2007. In 2008, there were about 22.05 million international tourists. Interestingly, in 2009, the tourist arrivals reach 15.38 million international visitors in the first three quarters of the year as revealed in Table 2 (Tourism Malaysia, 2009a). It is forecast that tourist arrivals will continue to grow at an average rate of $8.4 \%$, reaching 24.6 million tourists by 2010 (EPU, 2006; Khairudin, 2009). The rising importance of tourism in terms of its arrivals and receipts has forced the government to enlarge its budget distribution in its five-year development programs, currently the $9^{\text {th }}$ 
Malaysian Plan (2006 to 2010) to prepare the industry to be a key foreign exchange earner that contributes to growth, investment and employment (EPU, 2006). The top 10 markets in Malaysia are shown in Table 3 and the causes of highest expenditure are shown in Table 4.

Table 3: Top 10 Markets in Malaysia

\begin{tabular}{cll}
\hline No. & \multicolumn{1}{c}{ Country } & Arrivals (Million) \\
\hline 1. & Singapore & $11,003,492$ \\
2. & Indonesia & $2,428,605$ \\
3. & Thailand & $1,493,789$ \\
4. & Brunei & $1,085,115$ \\
5. & China & 949,864 \\
6. & India & 550,738 \\
7. & Japan & 433,462 \\
8. & Australia & 427,076 \\
9. & Philippines & 397,884 \\
10. & United Kingdom & 370,590 \\
\hline
\end{tabular}

Source: Tourism Malaysia, 2009

Table 4: Expenditures of International Tourists Visiting Malaysia

\begin{tabular}{lr}
\hline Expenditures of International Tourists Visiting Malaysia & Percentage (\%) \\
\hline Accommodation & 35.40 \\
Shopping & 25.70 \\
Food and beverage & 18.70 \\
Transportation & 10.10 \\
Entertainment & 3.70 \\
Others & 6.40 \\
Total & $\mathbf{1 0 0 . 0 0}$ \\
\hline
\end{tabular}

Source: Tourism Malaysia, 2007

In terms of demand for employees, in 2001, it accounted for 70,881 jobs and was planned to achieve 109,600 jobs in 2010 . The tour and travel agency segment is due to supply 18,200 jobs by 2010 (Ministry of Tourism, 2002). In 2007, the total workforce in Malaysia was 10.6 million employees, while the country's unemployment rate was 3\%. The tourism segment already provided a total of 1.2 million jobs, comprising $11.4 \%$ of overall employment in Malaysia (Department of Statistics, 2008). The tourism industry is increasingly a major source of employment, both directly and indirectly (WTTC, 2007). Even though the number of jobs provided in tourism is outsized, it was also reported that vacancies are not sufficiently filled by existing labour markets. In 2007, there were 35,953 vacancies in the hotel and restaurant segment alone (Ministry of Human Resource, 2008) and this has created a difference between the supply and demand in tourism employment in Malaysia. The requirements of the tourism industry experience forces education institutions to realize that they have to take a more active role. Malaysia is increasingly accepted by students from around the world as their preferred choice for tertiary tourism education. One of the primary reasons for the choice of Malaysia as an educational centre is the relatively low cost of living compared to the high quality of life. This is improved by technology. Students can discover more about the people, traditions and cultures while pursuing their education in Malaysia.

Tourism education has to find its place and role in faculties, departments and schools, providing the tourism industry with graduates who are able to respond to the challenges arising from this fast growing industry. Tourism education, the increase in the number of institutions of higher learning and twinning programs with foreign universities provide the foundation for the growth in tourism. Currently, more than 50,000 foreign students are registered with institutions of higher learning in the country. There are additional spins-offs as parents of foreign students take the opportunity to spend their holidays at tourist attractions when visiting their children. Tourism education has become popular as reflected by the demand for tours to visit universities to enable students from other countries to gain knowledge university system as well as experience the Malaysian university atmosphere, which is unique with the social interaction of the various ethnic groups besides contributing to the national economy. Presently, 2 government universities, 37 community colleges, 10 private institutions and 1 Foreign Branch Campus University offer tourism education (Office of the Higher Education Commission, 2009). Government universities have been established around Malaysia to provide for the higher education needs of those 
seeking to progress beyond secondary-level education. At least 2 of 20 universities provide tourism education. They are University of Malaysia Sabah (UMS) and University of Technology MARA (UiTM).

The community colleges in Malaysia where offer tourism education include Alor Gajah Community College, Arau Community College, Bayan Baru Community College, Bentong Community College, Bukit Beruang Community College, Jelebu Community College, Chenderoh Community College, Bandar Darul Aman Community College, Sungai Petani Community College, Langkawi Community College, Kulim Community College, Kepala Batas Community College, Teluk Intan Community College, Grik Community College, Sungai Siput (U) Community College, Pasir Salak Community College, Sabak Bernam Community College, Hulu Langat Community College, Selayang Community College, Hulu Selangor Community College, Kuala Langat Community College, Jempol Community College, Selandar Community College, Jasin Community College, Ledang Community College, Segamat Community College, Segamat 2 Community College, Bandar Penawar Community College, Tebrau Community College, Paya Besar Community College, Rompin Community College, Mentakab Community College, Kuantan Community College, Kuala Terengganu Community College, Tawau Community College, Kuching Community College and Mas Gading Community College.

Private universities also play an important role in providing tourism education in Malaysia. The private universities in Malaysia where offer tourism education include Multimedia, University of Tun Abdul Razak, University of Technology Petronas (UTP), University of Industry Selangor (UNISEL), Open University Malaysia, University of Tunku Abdul Rahman, Limkokwing University of Creative Technology (LUCT), Hyatt Regency Kuantan Hotel Training College, Nilai University College and Reliance School of Tourism. There is a foreign branch campus university in Malaysia. It is Curtin University of Technology, Sarawak Campus, Malaysia. The government is initiating many approaches in order to keep up with the changing world and current needs, which will generate a well-structured development of tertiary level education. The government has also clearly outlined the strategic thrusts in the National Higher Education Strategic Plan to make Malaysia an international centre of educational excellence by 2020; this certainly will include tourism education.

\section{Factors of Attribution in Thailand and Malaysia}

Major factors of Attribution in Thailand and Malaysia tourism are as follow:

- Tourism and hospitality is good because of the language proficiency of staff

- Nationwide transport service

- Reasonable room price

- Online booking facilities

Importantly, tourism education at the tertiary level both in Thailand and Malaysia were encouraged to develop the degree programs in tourism and related field by the governments. In particular, private universities offer tourism education programs because the tourism industry is one of the sectors they targeted. Another reason that these universities provide tourism education programs is because they attracted large numbers of students. Studying in these programs, in terms of expenses, the students are generally able to afford the experience. An additional reason is based on the students' interest in tourism education. Tourism education will lead them to opportunities to meet people from various cultures. This reason generates strong demand in having tourism education. However, the competitors in the tourism education market also increases. The growth of new universities that focus on providing tourism education make tourism education providers in Thailand take more active roles in putting their efforts to develop the curriculum to meet the students' needs, particularly through offering specialist options for students. Focusing on curriculum, there are high quality lecturers with excellent academic backgrounds, full of professionalisms qualifications and cultural research skills with positive attitude. Some universities coordinate with universities overseas to motivate student to join the program.

It is believed that the demand for tourism education will be a real decline in the future. Other programs may be closed as student demand decreases. Other programs maybe forced to adapt by merging, while others may continue to provide tourism as a minor subject only. One informant who is the Department Head of Hotel and Tourism Management at Sripatum University pointed out that even the best programs may not survive. As an alternative, the tourism education program which exists under the brand name of a university may also mean more than the quality. They believe that the graduate programs maybe the catalyst to revive the life cycle of such courses. 


\section{Conclusion and Recommendations}

Tourism education at the tertiary level is a very important part to drive both Thailand and Malaysia forward. It has been suggested that the future of tourism education in Thailand and Malaysia may be divided into two areas. First, there will be a collaborative program between universities and government tourism organizations which are funded and supported by the government. Second, the development of postgraduate programs for people who posses undergraduate qualifications in tourism and related fields to enhance their skills through acquiring additional qualifications to enhance their career prospects may also be offered. Focusing on languages, a range of languages is offered within the tourism education programs at the tertiary level to produce graduates to support the tourism market. Tourists who can speak English or Chinese may receive service support in the languages, while those who cannot may be disappointed. Tourism education at the tertiary level in Thailand enjoyed remarkable growth and the same situation also appertained in Malaysia. In both countries, now, there is sufficient supply at the undergraduate level. There is, though, a need for more post-graduate level students, which should be beneficial for the tourism industry in terms of long-term competitiveness. What is going to happen in the future? No one is positive but the number of undergraduate programs will decrease.

\section{References}

Baum, T. (2006). Human Resource Management for Tourism, Hospitality and Leisure: An International Perspective. London: Thomson Learning.

Busby, G. (2001). Vocationalism in Higher Level Tourism Courses: The British Perspective. Journal of Further and Higher Education, 25(1): 29-34.

Chaisawat, M. (2005). Travel and Tourism Education in Thailand. Journal of Teaching in Travel and Tourism, 5(3): 197-224.

Chon, K. S., Singh, A., and Mikula, J. R. (1993). Thailand's Tourism and Hotel Industry. Cornell Hotel and Restaurant Administration Quarterly, 34(3): 43-49.

Christou, E., and Singala, M. (2002). Innovation in Hospitality and Tourism Education. International Journal of Tourism Research, 4(1): 65-67.

Churchward, J. and Riley, M. (2002). Tourism Occupations and education: An Exploratory Study. International Journal of Tourism Research, 4(2): 77-86.

Cohen, E. (1996). Thai Tourism: Hill Tribes, Islands and Open-Ended Prostitution. Bangkok: White Lotus.

Da Silva, A. (2009). Thailand's Tourism Industry, Kapiolani Community College, Horizons. Available:http://bosp.kcc.hawaii.edu/Horizons/Horizons2002/Thailand_tourindusty.html [Accessed 6 June 2009].

Department of Statistic (2008). Key Statistics, Available: http://www.statistics.gov.my: Department of Statistics Malaysia. [Accessed 12 October 2009].

Economic Planning Unit (EPU) (2006). Realizing Tourism Potential: The 9th Malaysian Plan (2006-2010): Economic Planning Unit (EPU), Prime Minister's Department of Malaysia.

Ernawati, D. (2002). Tourism Education at the Tertiary Level in Indonesia: An Exploratory Study. International Journal of Tourism Research, 4(2): 145-150.

Goldsmith, A., \& Zahari, M. S. M. (1994). Hospitality Education in Malaysia: Filling the Skill Gap. International Journal of Contemporary Hospitality Management, 6(6): 27-31.

Gossling, S. (Ed). (2003). Tourism and Development in Tropical islands: Political Ecology Perspectives. Northampton: Edward Elgar Publishing, Inc.

Jennings, G. R. (2000). Educating Students to Be Lifelong Learners. Review of Business, 21(3/4): 58-62.

Khairudin, M. R. (2009). Tourism as a Graduate Career in Malaysia: Stakeholders' Perceptions. A Master Degree Thesis in Tourism Management. Victoria University of Wellington.

Knowles, T., Teixeira, R. M., and Egan, D. (2003). Tourism and Hospitality Education in Brazil and the UK: A Comparison. International Management, 15(1): 45-51.

Lam, T., and Xiao, H. (2000). Challenges and Constraints of Hospitality and Tourism Education in China. International Journal of Contemporary Hospitality Management, 12(5): 291-295.

Lauring, J. (2007). Language and Ethnicity in International Management. Corporate Communication: An International Journal, 12(3): 255-266.

Lee, M. N. N. (2004). Restructuring Higher Education in Malaysia. School of Educational Studies: Penang, Malaysia.

McKercher, B. (2002). The Future of Tourism education: An Australian Scenario? Tourism and Hospitality Research, 3(3): 199-210. 
Ministry of Human Resource. (2008). Human Resource and Labor Statistics: Vacancies reported to the Labor Department by Industry (2004-2007). Available: http:// www.mohr.gov.my [13 October 2009].

Ministry of Tourism (2008). Malaysia Tourism. Kuala Lumpur: Ministry of Tourism.

Ministry of Tourism (2002). A Study on the Human Resource Development in Tourism. Kuala Lumpur: Ministry of Tourism.

Office of the Higher Education Commission. (2009). Higher Education Information. Available: http://www.info.mua.go.th/CHE-pp2552/INFO_UNIV/ index.php?lang=en [Accessed 27 September 2009].

Ouyyanont, P. (2001). The Vietnam War and Tourism in Bangkok's Development, 1960-70. Southeast Asian Studies, 39(2): 157-187.

Poon. W. C., and Low, K. (2005). Are Travelers Satisfied With Malaysian Hotels? International Journal of Contemporary Hospitality Management, 17(3): 217-227.

Punmunin, W. (1993). What's happening to Thai Hospitality? Cornell Hotel and Restaurant Administration Quarterly, 34(3): 60-65.

Saibang, P. and Schwindt, R. C. (1998). The Need for Employee Training in Hotels in Thailand. International Journal of Training and Development, 2(3): 205-214.

Sangpikul, A. (2009). Internationalization of Hospitality and Tourism Higher Education: A Perspective from Thailand. Journal of Teaching in Travel and Tourism. 8(4): 71-87.

Thitthongkam, T., and Walsh, J. C. (2009). The Need for Language Skills Training for Tourism Company Staff in the Thai Tourism Industry: Managerial Perspectives. Proceedings of the 3rd International Colloquium on Tourism and Leisure (ICTL) 2009. 6th-9th July, Bangkok, Thailand.

Toatong, C. (2008). Why Tourism Educational Cooperation and Networking among the Southeast Asian Countries. Available: http://www.ttresearch.org/pdf/2551/325511.pdf [Accessed 26 September 2009].

Tourism Authority of Thailand Annual Report (2007). Annual Report. Available: http://www.tourismthaland.org [Accessed 5 June 2009].

Tourism Malaysia (2007). International Tourists' Expenditure Breakdown 2000-2006. InA. I. w. T. M. Sydney (Ed.).

Tourism Malaysia (2008a). Fast Facts about Malaysia. Available: [http://www.tourism.gov.my] [Accessed 13 October 2009].

Tourism Malaysia (2008b). About Tourism Malaysia. Available: [http://www.tourism.gov.my] [Accessed 13 October 2009].

Tourism Malaysia (2008c). Tourist Arrivals and Receipts to Malaysia, Available: [http://www.tourism.gov.my] [Accessed 13 October 2009].

Tourism Malaysia (2009a). Fast Facts about Malaysia. Available: [http://www.tourism.gov.my] [Accessed 13 October 2009].

Wells, R. J. G. (1982). Tourism Planning in a Presently Developing Country. Tourism Management, 98-107.

WTTC. (2007). Travel and Tourism Navigating the Path Ahead: The 2007 Travel and Tourism Economic Research. World Travel and Tourism Council. 